\title{
A Evaluation on the Road Manners of Vehicle Drivers in Chennai City
}

\author{
R. Ravimohan , CS.Gowtham, K.Poovarasan
}

\begin{abstract}
This project is to find out the road manners of the vehicle drivers (two, three, four) in critical signals at peak hours in Chennai city and also what are all the problems faced by the public because of the riders and drivers attitude. Also analyzing how the drivers are following the traffic rules on city roads. What are all the factors influencing the drivers for neglecting the traffic rules
\end{abstract}

Keywords ,Drivers. Vehicle, Road manners.

\section{INTRODUCTION}

1. To analyze the vehicles drivers towards General Road Manners.

2. To analyze Drivers attitude while they are driving the vehicles at critical points.

3. To study about impact of training provided in driving school towards vehicle Drivers.

4. To study about the attitude of drivers during Normal driving, Peak hour driving, Presence/Non presence of Traffic Policemen, jumping signals.

5. To analyze the causes for neglecting the traffic rules by the drivers.

6. To analyze the attitude of Drivers based on educational background. [1-10]

\section{SCOPE OF THE STUDY}

The study has been conducted to know the Drivers Attitude towards road manners. The interview has been directly conducted where observations and reality of underlying ideas or opinions are acquired.

With the collected information the researcher suggest to Joint Commission office that the strategies to improve the Road Manners of vehicle Drivers in Chennai City.

\section{A. Limitation:}

Time is main constraint, for a single researcher, it is difficult to be present at different traffic junctions at the same time within the available time[1-28]

\section{B. Research Design}

\section{RESEARCH METHODOLOGY}

The research method used for this research is descriptive in nature.A list of 17 localities was prepared by judgment after visiting traffic - dense locations.

\section{C.Sample size}

Revised Manuscript Received on July 22, 2019.

R. Ravimohan Department of Management studies,Bharath Institute of Higher Education and Research,Chennai,India

CS.Gowtham, Department of Management studies,Bharath Institute of Higher Education and Research,Chennai,India

K.Poovarasan, Department of Management studies,Bharath Institute of Higher Education and Research,Chennai,India

One hundred samples were collected from vehicle drivers.

2.3 Sampling Method

Sampling method used for this study was Convenience Sampling.

\section{D.Sources Of Data}

Primary data It was collected by personally observing road manners of vehicle drivers at selected traffic signals during peak and off-peak hour, the assistance from 2 of researchers friends was taken for vehicle identification.

Secondary data Secondary data was collected from the traffic constables and inspectors on duty at the places of study. Details were also collected from regional traffic officer (RTO) Aynavaram, Joint commissioner office (JC), Kilpauk. Such data was collected from internet[28-29]

\section{IV.ANALYSIS \& INTERPRETATION}

1.Really you follow the road man

Table No: 1

\begin{tabular}{|l|l|l|}
\hline Response & $\begin{array}{l}\text { No. Of } \\
\text { respondents }\end{array}$ & $\begin{array}{l}\text { Percentage } \\
\%\end{array}$ \\
\hline Yes & 80 & 80 \\
\hline No & 15 & 15 \\
\hline None & 05 & 05 \\
\hline Total & 100 & 100 \\
\hline
\end{tabular}

Interpretation:

The above table indicates that $80 \%$ of respondents follows the road manners, $15 \%$ not following, and $5 \%$ is none.

1.Really you follow the road manners

FIG:1

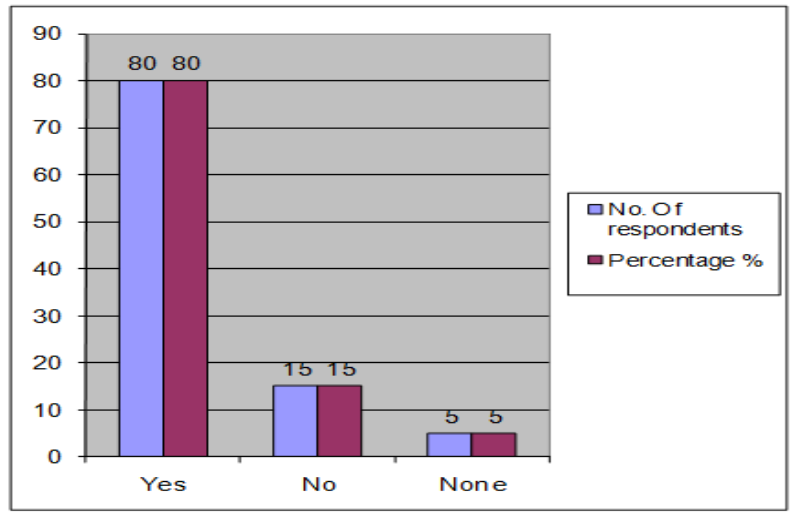


2. Opinion regarding the Road manners in Chennai:

Table No: 2

\begin{tabular}{|l|l|l|}
\hline $\begin{array}{l}\text { Respo } \\
\text { nse }\end{array}$ & $\begin{array}{l}\text { No.of } \\
\text { respon } \\
\text { dents }\end{array}$ & $\begin{array}{l}\text { Percentag } \\
\mathbf{e} \%\end{array}$ \\
\hline $\begin{array}{l}\text { It save } \\
\text { life }\end{array}$ & 20 & 20 \\
\hline $\begin{array}{l}\text { It save } \\
\text { time }\end{array}$ & 24 & 24 \\
\hline Both & 50 & 50 \\
\hline Others & 06 & 06 \\
\hline Total & 100 & 100 \\
\hline
\end{tabular}

Interpretation:

The above table indicates that $50 \%$ of respondents feels that its saves both, $20 \%$ feels its save life, $24 \%$ feels it save time, and $6 \%$ feels others.

2. Opinion regarding the Road manners in Chennai FIG:3

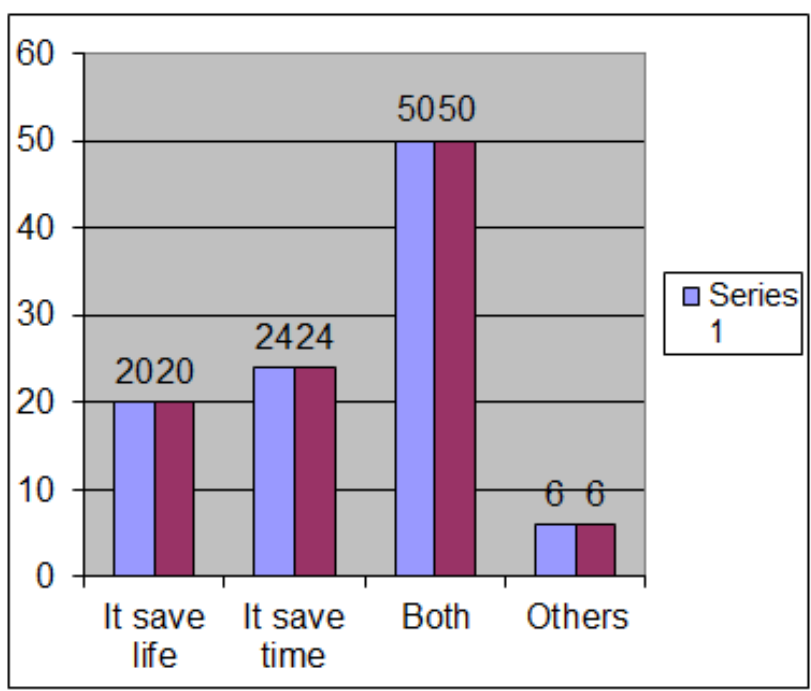

3. Really you follow the Signals:

Table No: 3

\begin{tabular}{|l|l|l|}
\hline Response & $\begin{array}{l}\text { No. } \\
\text { respondents }\end{array}$ & $\begin{array}{l}\text { Percentage } \\
\%\end{array}$ \\
\hline Yes & 75 & 75 \\
\hline No & 18 & 18 \\
\hline None & 07 & 07 \\
\hline Total & 100 & 100 \\
\hline
\end{tabular}

Interpretation:

The above table indicates that $75 \%$ of respondents follows the road manners, $18 \%$ not following, and $7 \%$ is none.
4.Adequate training is needed, while comparing with current: says no need, remaining $45 \%$ of respondents feels occasionally.

4.Adequate training is needed, while comparing with current: FIG:5

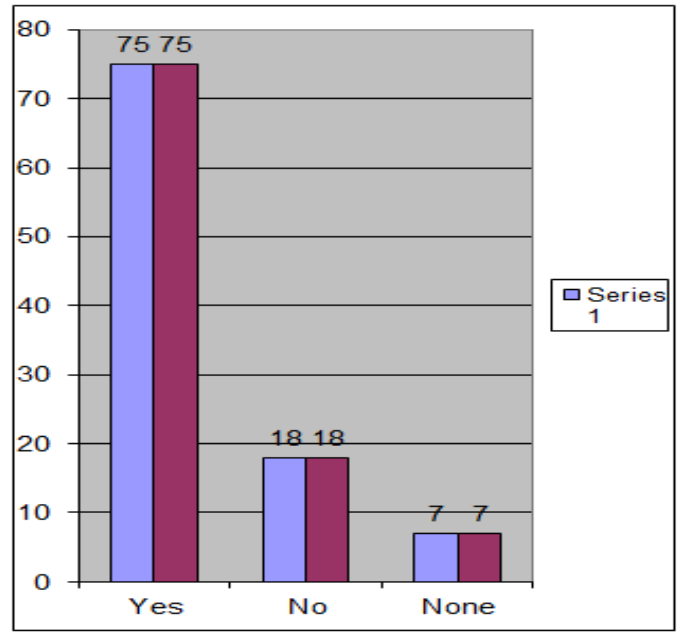

TABLE NO:4

\begin{tabular}{|l|l|l|}
\hline Response & No. Of respondents & Percentage \% \\
\hline Yes & 10 & 10 \\
\hline No & 45 & 45 \\
\hline Occasionally & 45 & 45 \\
\hline Total & 100 & 100 \\
\hline
\end{tabular}

Interpretation:

The above table indicates that $10 \%$ of respondents feel needed to adequate training, $45 \%$ feel

5. Drivers are following the speed limits:

FIG:6

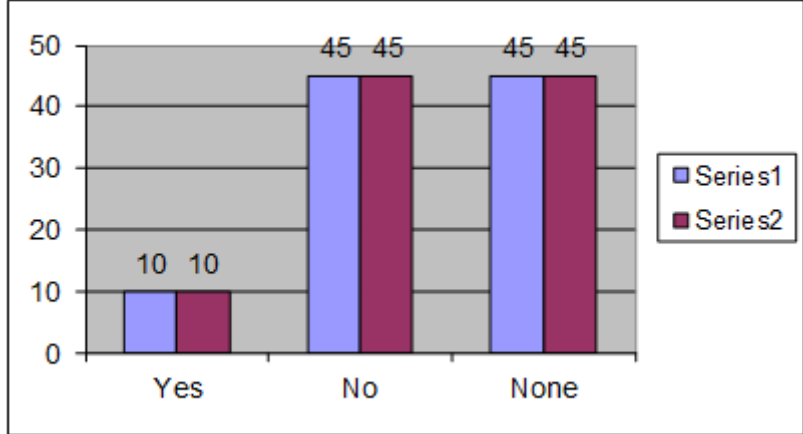

Published By:

Blue Eyes Intelligence Engineering \& Sciences Publication 
TABLE NO:5

\begin{tabular}{|l|l|c|}
\hline $\begin{array}{l}\text { Resp } \\
\text { onse }\end{array}$ & $\begin{array}{l}\text { No.of } \\
\text { respo } \\
\text { ndent } \\
\text { s }\end{array}$ & $\begin{array}{l}\text { Percent } \\
\text { age\% }\end{array}$ \\
\hline Yes & 30 & 30 \\
\hline No & 15 & 15 \\
\hline $\begin{array}{l}\text { Occsi } \\
\text { onaly }\end{array}$ & 52 & 52 \\
\hline None & 03 & 03 \\
\hline Total & 100 & 100 \\
\hline
\end{tabular}

Interpretation:

The above table indicates that $30 \%$ of respondents feel following the speed limits, $15 \%$ feels not following, $52 \%$ feel occasionally, and $3 \%$ feels none.

5. Drivers are following the speed limits FIG:7

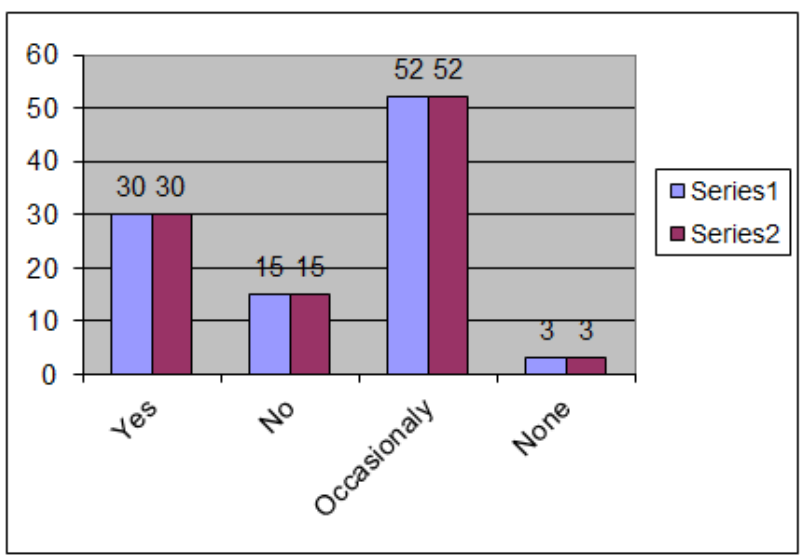

6.Opinion about Chennai Traffic

TABLE NO:6

\begin{tabular}{|l|l|l|}
\hline Response & $\begin{array}{l}\text { No.Of } \\
\text { respondent } \\
\text { s }\end{array}$ & $\begin{array}{l}\text { Percentage } \\
\%\end{array}$ \\
\hline $\begin{array}{l}\text { Very } \\
\text { good }\end{array}$ & 11 & 11 \\
\hline Good & 35 & 35 \\
\hline Better & 42 & 42 \\
\hline None & 12 & 12 \\
\hline Total & 100 & 100 \\
\hline
\end{tabular}

Interpretation:
The above table indicates that $11 \%$ of respondents feels Chennai traffic is very good, $35 \%$ feels good, $42 \%$ feels better, and $12 \%$ feels none.

6.Opinion about Chennai Traffic:

FIG:8

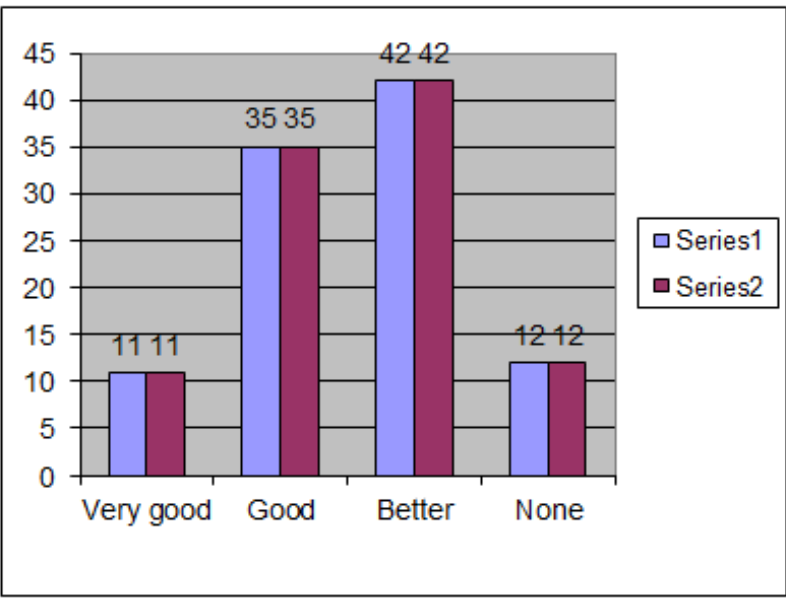

7. General road driving easy than City driving:

TABLE NO: 7

\begin{tabular}{|c|c|c|}
\hline Response & $\begin{array}{l}\text { No.Of } \\
\text { respondents }\end{array}$ & Percentage\% \\
\hline Yes & 20 & 20 \\
\hline No & 80 & 80 \\
\hline Total & 100 & 100 \\
\hline
\end{tabular}

Interpretation:

The above table indicates that $20 \%$ of respondents says General road driving easy than City driving, $80 \%$ says not easy.[30]

\section{V.RESULTS}

Number of drivers not following the speed limits:

Two-wheeler: $40 \%$ of the two-wheelers are not following the speed limits.

Three-wheeler: $25 \%$ of the three-wheelers are not following the speed limits.

Four-wheeler: $15 \%$ of the four-wheelers are not following the speed limits.

Number of drivers not following the signal rules:

Two-wheeler: $50 \%$ of the two-wheeler riders are not following the signal rules.[31]

Three-wheeler: $20 \%$ of the three-wheeler riders are not following the signal rules.

Four-wheeler: $30 \%$ of the four-wheeler riders are not following the signal rules.

Number of drivers not using the precautionary tools while driving: 
Two-wheeler: $20 \%$ of the two-wheeler riders are not using the precautionary tools.

Four-wheeler: $40 \%$ of the four-wheeler riders are not using the precautionary tools.[32]

\section{DISCUSSION}

Giving counseling to the vehicle drivers about the demerits of speed driving[33]

\section{- Speed thrills but kills}

Traffic constables should be allocated at every signal.

- Vehicle Drivers should be educated about the signals.

Motivate the vehicle drivers to follow-up the precautionary tools while driving like

- Using helmet while riding

- Using seat belt while driving

Training should be adequately provided to drivers in driving schools.

\section{VII.CONCLUSION}

The project work done in Vehicle Drivers to identifying the Drivers behaviour towards Road Manners in Chennai. Drivers responded the questionnaire and it was found the analysis that the driver's behaviour is satisfactory.

The project work success highly depends on public i.e., vehicle drivers they responded clearly and they cooperated.

\section{REFERENCES}

1) BharthVajan R., Ramachandran S.,Psychographic dimensions of training,2016,International Journal of Pharmacy and Technology,V-8,I-4,P-23727-23729

2) Balakrishnan P., Bharthvajan R.,A study on human resource planning in hospitals in Chennai City,2014,International Journal of Applied Engineering Research,V-9,I-22,P-7503-7507

3) Priyadarsini P., Bharthvajan R.,Role of emotional intelligence training programme in reducing the stress of the nurses,2014,International Journal of Applied Engineering Research,V-9,I-22,P-7411-7421

4) Kerinab Beenu G., Bharthvajan R.,Empirical analysis on the cosmetic buying behavior of young women in South India,2014,International Journal of Applied Engineering Research,V-9,I-22,P-7361-7366

5) Balakrishnan P., Bharthvajan R.,Whistling in the wind,2014,International Journal of Applied Engineering Research,V-9,I-22,P-7586-7593

6) Krishnan B., Peter M.,Health hazards of Indian Bpo employee-an alarming issue,2014,International Journal of Applied Engineering Research,V-9,I-22,P-7336-7341

7) Kerinab Beenu G.H., Peter M.,Role of insurance in economic development,2014,International Journal of Applied Engineering Research,V-9,I-22,P-7532-7539

8) Balakrishnan P., Peter M., Priyadarsini P.,Efficiency of safety measures for wellbeing of employees in manufacturing industry,2014,International Journal of Applied Engineering Research,V-9,I-22,P-7376-7382

9) Anbarasi M., Praveen Kumar S.,Online sales promotions of herbal products and its effectiveness towards tanisha.com,2019,Indian Journal of Public Health Research and Development,V-10,I-1,P-195-200
10) Anbarasi M., Praveen Kumar S.,Various online marketing and promotions strategies to improve the validation towards the organic products in the pharmaceutical sectors,2019,Indian Journal of Public Health Research and Development,V-10,I-1,P-263-269

11) Loganathan R., Praveen Kumar S.,Grievance handling a key factor for solving issues of employees in an organization,2014,International Journal of Applied Engineering Research,V-9,I-22,P-7483-7491

12) Loganathan R., Praveen Kumar S.,Study on preference of private label brands in super and Hypermarkets,2014,International Journal of Applied Engineering Research,V-9,I-22,P-7327-7335

13) Smitha M., Praveen Kumar S.,Understanding stress and its managementamong the nurses in Chennai city,2014,International Journal of Applied Engineering Research,V-9,I-22,P-7560-7565

14) Kerinab Beenu G.H., Praveen Kumar S.,A study on the investment behavior of Chennai investors in mutual fund schemes,2014,International Journal of Applied Engineering Research,V-9,I-22,P-7520-7525

15) Loganathan R., Praveen Kumar S.,Retention strategies key for organizational productivity,2014,International Journal of Applied Engineering Research,V-9,I-22,P-7443-7447

16) Pavithra J., Ganesan M., Brindha G.,State wise analysis of microfinance sector in India,2016,International Journal of Pharmacy and Technology,V-8,I-4,P-23417-23432

17) Pavithra J., Ganesan M.,A comparative study on microfinance in India and abroad,2016,International Journal of Applied Business and Economic Research,V-14,I-8,P-5471-5476

18) Pavithra J., Ganesan M.,A study on awareness and impact of micro-financial schemes,2016,International Journal of Applied Business and Economic Research,V-14,I-8,P-5449-5460

19) Senthilmurugan P., Pavithra J.,Consumer preference towards organised retailing with reference to Big Bazaar,2014,International Journal of Applied Engineering Research,V-9,I-22,P-7469-7475

20) Senthilmurugan P., Pavithra J.,Implication of social media marketing in growing healthcare industry,2014,International Journal of Applied Engineering Research,V-9,I-22,P-7448-7456

21) Loganathan R., Pavithra J.,Consumer perception towards private label brand over other brands in super markets and hypermarkets,2014,International Journal of Applied Engineering Research,V-9,I-22,P-7355-7360

22) Kerinab Beenu G., Pavithra J.,Tradeâ€"off between liquidity and profitability in logistics industry,2014,International Journal of Applied Engineering Research,V-9,I-22,P-7398-7401

23) Kerinab Beenu G., Pavithra J.,A study on the prospective consumerâ $€^{\mathrm{TM}_{\mathrm{S}}}$ perception towards utility cars in Chennai city,2014,International Journal of Applied Engineering Research,V-9,I-22,P-7526-7531

24) Pavithra J., Dilli Babu P., Ambuli T.V.,A study on budgetary control at Maruti Service Masters, Chennai,2014,International Journal of Applied Business and Economic Research,V-12,I-2,P-151-161

25) Pavithra J., Dilli Babu P., Ambuli T.V.,A study on customer satisfaction of retro Garments Pvt Ltd, Chennai,2014,International Journal of Applied Business and Economic Research,V-12,I-2,P-381-391

26) Kerinab Beenu G.H., Pavithra J., Senthilmurugan P.,A study on the influence of promotional activities for TATA ARIA among consumers in Chennai,2014,International Journal of Applied Engineering Research,V-9,I-22,P-7572-7578

27) Vijayaragavan S.P.,An investigative expert that's general FBG sensors, International Journal of Mechanical Engineering and Technology,V-8,I-8,PP-1500-1505,Y-2017

28) Vijayaragavan S.P.,Equalization routing protocol for Wi-Fi sensor strategy,International Journal of Mechanical Engineering and Technology,V-8,I-8,PP-1662-1666,Y-2017

29) Karthik B., Kiran Kumar T.V.U., Vijayaragavan P., Bharath Kumaran E.,Design of a digital PLL using 0.35 $\hat{\mathrm{I}}^{1} / 4 \mathrm{~m}$ CMOS technology,Middle East Journal of Scientific Research,V-18,I-12,PP-1803-1806,Y-2013

30) Kanniga E., Selvaramarathnam K., Sundararajan M.,Kandigital bike operating system,Middle - East Journal of Scientific Research,V

31) Jasmin M., Vigneshwaran T., Beulah Hemalatha S.,Design of power aware on chip embedded memory based FSM encoding in FPGA,International Journal of Applied Engineering Research,V-10,I-2,PP-4487-4496,Y-2015 
32) Jasmin M.,Optimization techniques for low power VLSI circuits,Middle - East Journal of Scientific Research,V-20,I-9,PP-1082-1087,Y-2014

33) Jasmin M., Vigneswaran T.,Fuzzy controller for error control of on Chip communication,2017 International Conference on Algorithms, Methodology, Models and Applications in Emerging Technologies, ICAMMAET 2017,V-2017-January,I-,PP-1-5,Y-2017

\section{AUTHORS PROFILE}

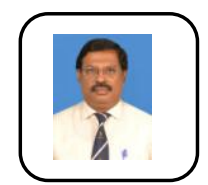

R. Ravimohan. Assistant Professor, Department of Management Studies,Bharath Institute of Higher Education and Research.

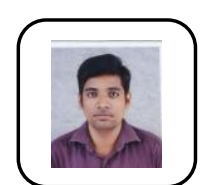

CS.Gowtham ,Assistant Professor, Department of Management Studies ,Bharath Institute of Higher Education and Research.

K.Poovarasan ,Student, Department of Management Studies, Bharath Institute of Higher Education and Research. 